\title{
PENDEKATAN DESAIN BERBASIS POLA PERILAKU DAN PANOPTIK PADA RUMAH INTERAKTIF ANAK JALANAN DAN HEWAN TERLANTAR DI CIRACAS
}

\author{
Ruby Sutanto ${ }^{1)}$, Priscilla Epifania Ariaji2) \\ 1)Program Studi S1 Arsitektur, Fakultas Teknik, Universitas Tarumanagara, rubysutanto2411@gmail.com \\ 2) Program Studi S1 Arsitektur, Fakultas Teknik, Universitas Tarumanagara, priscillae@ft.untar.ac.id
}

\begin{abstract}
Abstrak
Permasalahan tentang anak-anak jalanan dan hewan terlantar di perkotaan masih menjadi suatu hal yang kurang mendapatkan perhatian. Perancangan rumah interaktif ini bertujuan untuk menampung dan memberikan ruang hidup yang lebih layak dan terjamin serta adanya campur tangan pemerintah dan masyarakat di dalamnya. Hal ini tentu saja membutuhkan pendekatan khusus dalam perancangan dan perencanaannya. Masingmasing penghuni memiliki karakter yang berbeda dan juga ekosistem yang berbeda. Perlu adanya pengamatan pola perilaku dari penghuni bangunan untuk mengetahui kebutuhan ruang yang sesuai dengan perilaku penggunanya serta dapat mengaplikasikannya dengan tepat. Lalu pendekatan panoptik terhadap bentuk pola massa bangunan yang bertujuan untuk memudahkan dalam proses pengawasan terhadap penghuni dan arsitektur ikut berperan dalam proses pengawasan terhadap penghuni bangunan. Pola perilaku setiap penghuni yang berbeda tentu saja membutuhkan pengaplikasian yang berbeda di setiap perancangan ruang di dalamnya, terlebih lagi sebagai hunian massal yang merupakan ekosistem barunya kelak. Oleh sebab itu, pendekatan pola perilaku dan panoptik ini diterapkan pada bangunan untuk mempertimbangkan aspek-aspek desain yang dibutuhkan dan dapat diterapkan dengan tepat serta sesuai dengan penghuni bangunan itu sendiri yang memiliki ekosistem dan ruang hidup yang berbeda.
\end{abstract}

Kata kunci: anak jalanan; hewan terlantar; panoptik; perilaku; rumah interaktif

\begin{abstract}
The problem of street children and abandoned animals in urban areas is still something that gets less attention. The design of this interactive house aims to accommodate and provide a more decent and secure living space as well as the intervention of the government and the community in it. This of course requires a special approach in its design and planning. Each resident has a different character and also a different ecosystem. It is necessary to observe the behavior patterns of building occupants to find out the space requirements that are in accordance with the behavior of the users and can apply them appropriately. Then the panoptic approach to the shape of the mass pattern of the building which aims to facilitate the process of monitoring the occupants and architecture plays a role in the process of monitoring the occupants of the building. The different behavior patterns of each occupant of course require different applications in each space design on it, especially as a mass $d$ welling which is the new ecosystem in the future. Therefore, this behavioral and panoptic pattern approach is applied to buildings to consider the design aspects needed and can be applied appropriately and in accordance with the building's occupants who have different ecosystems and living spaces.
\end{abstract}

Keywords: abandoned animals; behaviour; interactive house; panoptic; street children

\section{PENDAHULUAN}

Krisis sosial yang kerap dialami oleh penghuni kota yang termarjinalisasi ini sudah sangat sering menimbulkan permasalahan yang cukup rumit. Pada kasus anak jalanan, permasalahan yang terjadi seperti eksploitasi, kekerasan terhadap anak, dan lainnya. Sedangkan pada hewanhewan liar di jalanan seperti kekerasan, eksploitasi, konflik dengan masyarakat, hingga bisnis 
daging hewan untuk konsumsi. Oleh sebab itu, perlu adanya kesadaran masyarakat kota terhadap permasalahan ini, serta pemerintah yang dapat mengatasi permasalahan ini melalui wadah atau ruang yang dapat menampung dan memberikan kehidupan lebih layak terhadap penghuni kota yang termarjinalisasi ini.

\section{Latar Belakang}

Anak-anak jalanan dan hewan terlantar yang merupakan penghuni kota yang termarjinalisasi tentu saja memiliki ruang lingkup untuk hidup yang berbeda dari anak-anak atau hewan pada umumnya. Perilaku yang mereka dapatkan selama ini jauh berbeda daripada proses bertumbuh dan berkembang yang normal. Masalah ini timbul dikarenakan faktor kemiskinan, ketidaksejahteraan, dan faktor-faktor lainnya. Anak jalanan merupakan bagian dari Penyandang Masalah Kesejahteraan Sosial (PMKS) yang faktor penyebabnya seperti yatim-piatu, korban penculikan, faktor kemiskinan, serta lainnya. Sedangkan hewan terlantar banyak ditemukan di perkotaan karena adanya eksploitasi oleh oknum tidak bertanggung jawab, atau penelantaran oleh pemilik hewan tersebut dan karena adanya perkembangbiakan oleh hewan-hewan di jalanan yang tidak terkendali.

\section{Rumusan Permasalahan}

Dalam proses mendesain perlu adanya pemikiran dan strategi dalam tahap perancanaannya, dari berbagai aspek harus sangat diperhatikan agar bangunan tersebut dapat berperan sesuai fungsi dan tujuan utamanya. Melalui pendekatan pola perilaku dan panoptik yang diterapkan pada hunian anak jalanan dan hewan terlantar ini, bagaimanakah pendekatan itu dapat menghasilkan suatu desain yang membuat penghuninya nyaman dan merasa tidak nyaman. Serta melalui pendekatan pola perilaku dan panoptik, pendekatan dalam aspek desain manakah yang akan diterapkan atau dapatkah menerapkan kedua pendekatan tersebut dalam bangunan ini.

\section{Tujuan}

Pendekatan melalui pola perilaku masing-masing target pengguna bangunan bertujuan untuk mengetahui dan memahami apa yang menjadi kebutuhan bagi penggunanya melalui peran arsitektur. Selain itu pendekatan panoptik diterapkan dalam desain massa bangunan yang bertujuan untuk mempermudah pengawasan terhadap para penghuni bangunan agar lebih efisien dari segi jumlah pengawas maupun peran arsitektur yang bergerak di dalamnya. Serta pendekatan panoptik yang diterapakan melalui pola bangunan, bertujuan untuk proses pengawasan yang lebih ketat dan efisien serta arsitektur juga dapat berperan serta dalam proses pengawasan di dalamnya.

\section{KAJIAN LITERATUR}

Strategi desain yang diterapkan dalam desain melalui pemahaman pola perilaku pengguna bangunan dan juga pendekatan panoptik terhadap bentuk massa pola bangunan dan ruang didalamnya.

\section{Pendekatan desain melalui pola perilaku pengguna bangunan}

Strategi desain yang diterapkan dalam desain melalui pemahaman pola perilaku pengguna bangunan. Pola perilaku diterapkan melalui pengamatan dan analisis perancang untuk mendapatkan hasil desain yang sesuai bagi pengguna bangunannya. Pendekatan desain melalui pengamatan pola perilaku dikemukakan oleh Atelier Bow Bow yang merupakan salah satu firma arsitektur di Jepang. Arsitektur berdasar tingkah laku tidak bisa hanya dijelaskan dengan penggunaannya saja dan tidak hanya dengan bentuk. Perilaku dapat ditempatkan di antara bentuk dan penggunaannya. Dalam pengertian itu, perilaku sesuai dengan praktik tata ruang. 


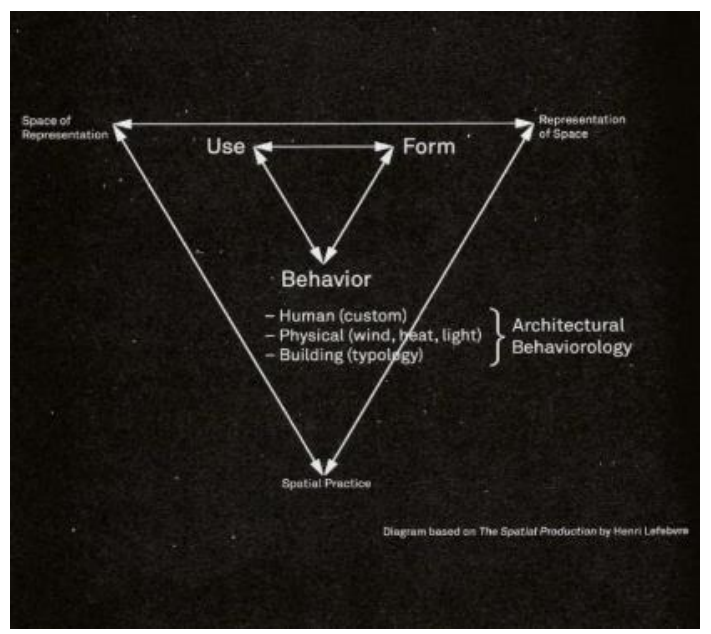

Gambar 1. Diagram Pola Perilaku

Sumber: Henri Lfebvre

Pada dasarnya "Arsitektur berdasarkan perilaku" yang harus diamati sangatlah luas, mulai dari Perilaku manusia atau penggunanya serta fenomena fisik hingga tipologi bangunan dan juga efeknya terhadap alam sekitar.

\section{Karakter desain berdasarkan pendekatan panoptik}

Panoptik (Panopticon) adalah suatu jenis bangunan kelembagaan yang di desain oleh seorang filsuf dari Ingris dan sosial teori Jeremy Bentham di akhir abad ke-18. Pendekatan desain ini adalah untuk memungkinkan pengamat atau pengawas untuk mengamati (-opticon) semua (pan-) penghuni atau pengguna bangunan tanpa mereka bisa mengatakan atau merasa sedang diawasi. Pada umumnya, konsep atau pendekan panoptik ini diterapkan pada bangunanbangunan berbasis lembaga seperti penjara, rumah sakit, panti sosial, pusat rehabilitasi, penangkaran, dan sebagainya yang membutuhkan pengawasan lebih khusus dan mempermudah pengawas dalam mengawasi pengguna bangunan di dalamnya.

Menurut Michael Foucault (1790) Konsep atau pendekatan panoptik ini menjelaskan tentang hubungan atau relasi antara subjek yang mengawasi dan diawasi, subjek yang mengawasi dan diawasi, subjek yang mengontrol maupun dikontrol, subjek yang menormalkan dan abnormal dalam sebuah ruang kekuasaan, tanpa kontak secara langsung. Efek yang akan ditimbulkan melalui peran panoptik dalam bangunan adalah menimbulkan kesadaran untuk diawasi, dilihat, diperhatikan secara terus-menerus sehingga seseorang dapat sadar bahwa segala gerak-gerik dan tindakannya selalu ada yang melihat dan mengawasi. Hal ini akan menimbulkan rasa patuh bahkan tekanan dan ketakutan.

Hasil dari efek kepatuhan, tekanan, maupun ketakutan yang muncul dari desain bangunan yang menerapkan panoptik ini adalah dapat memberikan kesadaran maupun efek jera terhadap penghuni atau pengguna bangnan di dalamnya. Betham dalam rancangan bangunan yang menerapkan panoptik selain untuk mendisiplinkan, namun juga dimaksudnkan untuk meminimalisir biaya penanganan dan perawatan agar lebih murah dan efisien, karena mudahnya pengawasan maka tidak perlu memperkerjakan banyak staff di dalamnya.

Namun dalam proyek ini, tujuan utamanya bukan untuk menakut-nakuti maupun membuat tekanan pada pengguna melainkan untuk memudahkan dan efisiensi dalam proses pengawasan. Karena pengguna bangunan memiliki ekosistem yang berbeda-beda dan merupakan subjek yang sedang bertumbuh dan berkembang yang perlu untuk diawasi secara khusus.

Desain panoptik terdiri atas struktur melingkar dengan ruang pengawas di tengah pusatnya, dimana para pengawas dapat mengontrol, mengawasi, dan mengamati seluruh pergerakan subjek-subjek yang berada disekelilingnya tanpa sadar bahwa mereka sedang diawasi. Teritori berfungsi sebagai pemicu agresi namun juga dapat menjadi stabilisator untuk mencegah timbulnya gerakan agresi, karena agresi lebih sering terjadi pada kondisi teritori yang belum 
terbentuk nyata atau dalam perebutan. Perebutan area teritori sangat sering terjadi di penjara maupun lembaga sosial lainnya yang berbasis hunian.

Jika para penghuni diberikan kesempatan untuk memiliki batas wilayah teritori pribadi mereka, maka suasana dan atmosfer sosial yang tercipta antar unit maupun ekosistem dapat meningkatkan perasaan postif (Barton, 1996; Holahan, 1967; Holahan \& Saegert, 1973). Batasan teritori yang jelas akan mampu menciptakan stabilitas dalam suatu ekosistem dan mengurangi perseteruan antar kelompok manusia dan juga berlaku pada binatang ( $O^{\prime}$ Neal \& McDonald, 1976).

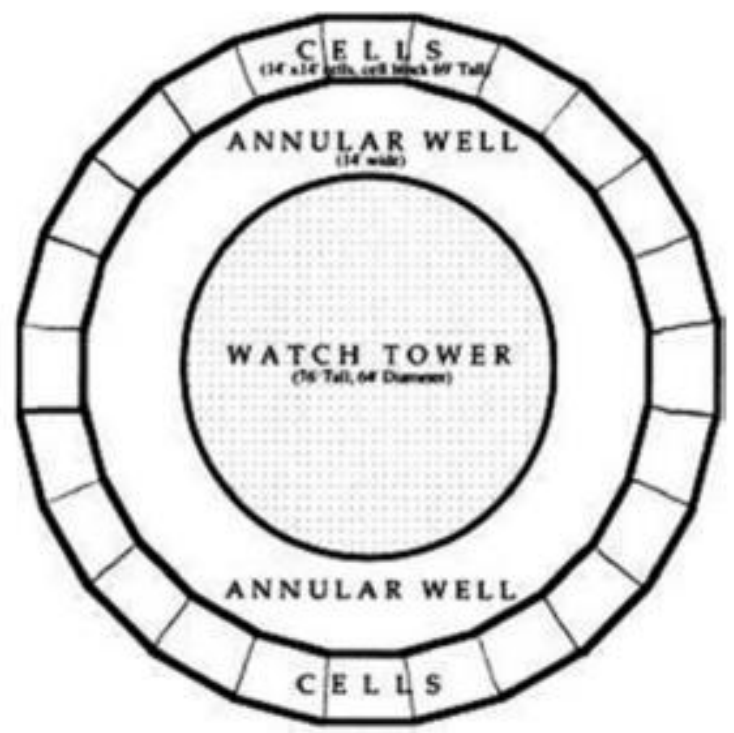

Gambar 2. Pola Ruang Penjara Melalui Pendekatan Panoptik Sumber: Bentham, 1791

\section{METODE}

Penerapan pendekatan pola perilaku dan panoptik diaplikasikan pada desain bangunan Rumah Interaktif Anak Jalanan dan Hewan Terlantar di Ciracas ini melalui pengamatan secara langsung terhadap tingkah laku target pengguna bangunan, seperti anak jalanan, anjing, kucing, kuda, dan monyet yang terlantar atau mengalami eksploitasi. Setelah itu dengan mencari teori dan studi terkait terhadap perilaku dan relasi antara manusia dan hewan karena merupakan jenis mahluk hidup yang berbeda dan memerlukan ruang hidup yang berbeda. Melalui studi dan pengamatan yang sudah dilakukan, perlu adanya analisis yang dapat menghasilkan desain yang dapat diaplikasikan penerapannya terhadap bangunan melalui pendekatan pola perilaku masingmasing target pengguna bangunan. Selain itu, penerapan panoptik lebih berperan dalam pendekatan desain pola bentuk bangunan. Melalui studi literatur dan teori-teori yang ada, panoptik dapat diterapkan pada bangunan-bangunan yang difungsikan sebagai hunian massal dan membutuhkan pengawasan secara lebih khusus. Oleh sebab itu, penelitian perlu dilakukan juga terhadap target pengguna bangunan akan kebutuhan ruang yang diperlukan dan membutuhkan pengawasan secara khusus, sehingga penerapan panoptik dapat diterapkan pada area atau zona tertentu pada bangunan ini.

\section{DISKUSI DAN HASIL}

Penerapan pendekatan tingkah laku dan panoptik dalam perancangan bangunan ini menghasilkan beberapa aspek penting yang harus diterapkan dalam proses perancangan bangunan dan penentuan program ruang yang diberikan. Serta penerapan panoptik pada bangunan yang diaplikasikan melalui bentuk pola massa bangunan yang berkesinambungan. 


\section{Analisis}

Penerapan desain berdasarkan pemahaman pola perilaku pengguna bangunan

Pola perilaku pengguna bangunan yang berbeda-beda namun memiliki beberapa kesamaan diantaranya dapat menjadi suatu ide perancangan yang dapat dituangkan dalam bangunan dan dapat digunakan bersama dan juga menghasilkan interaksi antar penghuni di dalam bangunan tersebut. Pola perilaku beragam yang ada diantara para pengguna bangunan ini, misalnya anakanak yang gemar bermain dan berlari-larian dan juga ada beberapa hewan misalnya anjing dan kucing yang gemar bermain dan kuda yang harus berlari menjadikan suatu aspek perancangan yang dapat dijadikan dalam satu program interaksi antar penghuni di dalamnya.
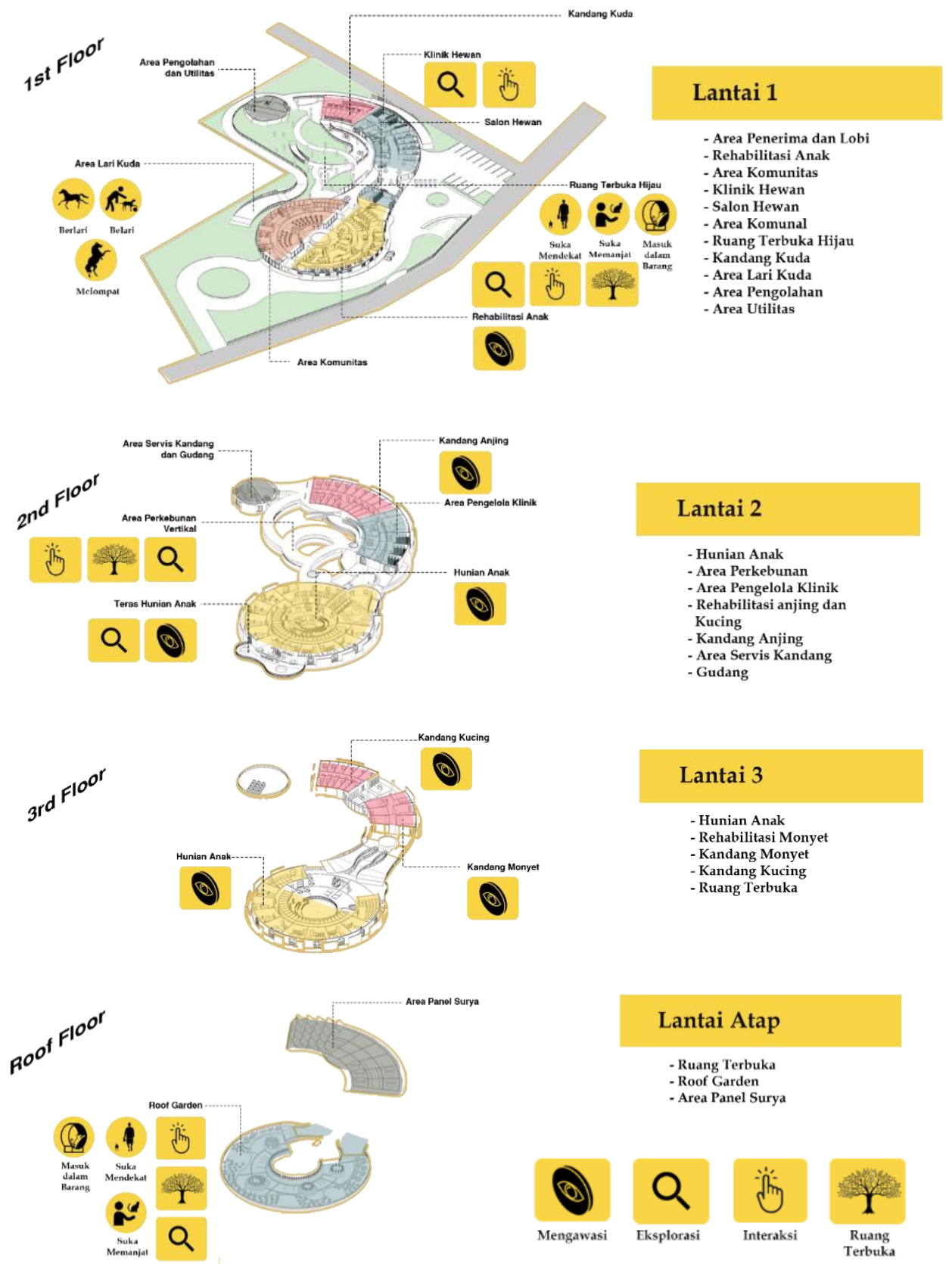

Gambar 3. Penerapan Pola Perilaku dalam Perancangan Sumber: Olahan Pribadi, 2021

Melalui program-program dan kebutuhan ruang yang diberikan, dapat dilihat bahwa bangunan memberikan ruang dan wadah yang memiliki fungsi untuk memenuhi kebutuhan para 
penghuninya. Selain itu pengaplikasian 4 aspek penting pada bangunan ini yaitu, pengawasan, eksplorasi, ruang terbuka, dan interaksi sudah diterapkan di masing-masing ruang atau area pada bangunan. Selain itu, yang paling terpenting adalah pengaplikasian atau diberikannya suatu wadah ruang untuk para penghuni maupun pengguna bangunan agar dapat saling berinteraksi satu sama lain dalam satu area komunal atau terbuka. Hal ini dapat ditemukan pada bangunan, dimana banyaknya titik-titik area komunal baik ruang terbuka atau didalam bagunan yang berfungsi sebagai celah atau wadah untuk berinteraksi.

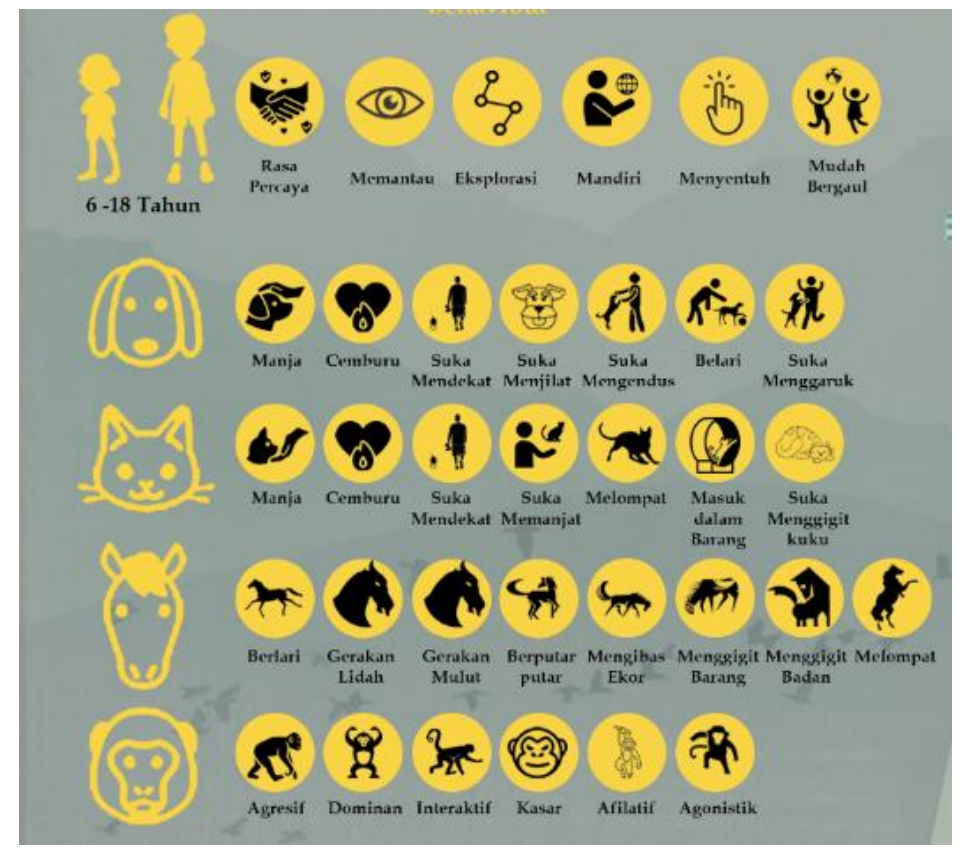

Gambar 4. Tingkah Laku Pengguna Bangunan

Sumber: Olahan Pribadi, 2021

\section{Pendekatan panoptik dalam perancangan bangunan}

Pola ruang luar maupun dalam bangunan perlu di rencanakan dengan baik mengingat bangunan ini merupakan suatu lembaga sosial yang berfungsi sebagai hunian massal, terlebih penghuni yang menempati memiliki ekosistem yang berbeda-beda dan berasal dari latar belakang yang berbeda-beda. Panoptik merupakan salah satu pendekatan yang digunakan dan diaplikasikan dalam perencanaan rancangan bangunan ini. Pendekatan panoptik dalam bangunan ini bukan bermaksud untuk menakut-nakuti maupun memberikan efek jera terhadap penghuni di dalamnya, melainkan kaidah bentuk perancangan ruang yang diterapkan. Hal ini sejalan dengan tujuan penerapan panoptik pada awalnya, agar masing-masing penghuni merasa memiliki wilayah teritorinya masing-masing dan meminimalisir adanya konflik internal sesama penghuni di dalamnya. Selain itu untuk meminimalisir kebutuhan pengawas yang mengawasi banyaknya penghuni di dalam bangunan, dalam kata lain agar desain bangunan yang berperan langsung dalam pengawasan terhadap masing-masing penghuni. Hal ini akan membuat penghuni bangunan juga merasa nyaman dan aman serta tidak merasa takut dan merasa diawasi oleh banyak orang karena arsitektur yang berperan langsung dalam proses pengawasan tersebut.

\section{Program Ruang}

Dalam perancangan proyek ini, tapak perancangan memiliki luas $8.307 \mathrm{M}^{2}$ dengan KDB 30\% yaitu $2.492 \mathrm{M}^{2}$ yang pada perancangannya terbangun $2.066,04 \mathrm{M}^{2}$ sebagai bangunan dan pengerasan. Oleh sebab itu, pada tapak perancangan akan lebih banyak terdapat lahan-lahan yang diaplikasikan sebagai ruang terbuka hijau dan berfungsi sebagai area komunal dan area 
untuk memenuhi aspek-aspek perancangan yang dihasilkan dari pemikiran pendekatan pola perilaku pengguna bangunan. Selain itu, dengan KLB 0,9 yaitu $7.463 \mathrm{M}^{2}$ yang pada perancangannya terbangun $7.231 \mathrm{M}^{2}$ sebagai luas bangunan keseluruhan, terdapat beberapa titik ruang terbuka lainnya, baik didalam bangunan sebagai ruang, maupun taman taman terbuka di bangunan tersebut. Terdapat 9 titik area atau wadah interaksi di dalam bangunan yang tersebar dari lantai dasar hingga roof garden.

\section{Strategi Desain}

Melampaui Ekologi menuju arsitektur untuk kebaikan diwujudkan dalam proyek ini melalui penanganan terhadap kaum-kaum termarjinalisasi dan tersingkir di perkotaan yang luput dari perhatian masyarakat awam dan pemerintah. Memberikan wadah dan ruang baru yang lebih layak bukanlah menjadi hal yang mudah, karena sebelumnya mereka tidak memiliki proses tumbuh dan berkembang bagaimana yang selayaknya. Oleh sebab itu, perlunya perhatian dan pengamatan terhadap pola perilaku target pengguna bangunan agar dapat memberikan kenyamanan terhadap pengguna bangunan ketika aktivitas didalamnya sudah terwujudkan dan beroperasi. Hal ini pasti penting dalam jenis-jenis bangunan sosial yang berfungsi sebagai hunian, karena pentingnya perhatian secara psikologis terhadap penghuninya yang sudah banyak mengalami trauma dan gangguan psikologis sebelumnya.

Melalui pendekatan desain melalui pola perilaku dan penerapan panoptik pada pola bentuk massa bangunan, pengaplikasian diterapkan pada seluruh bagian bangunan baik interior maupun eksterior bangunan. Selain itu pendekatan desain juga mencakup 4 aspek penting yaitu, pengawasan, eksplorasi, ruang terbuka, dan interaksi.

Eksplorasi
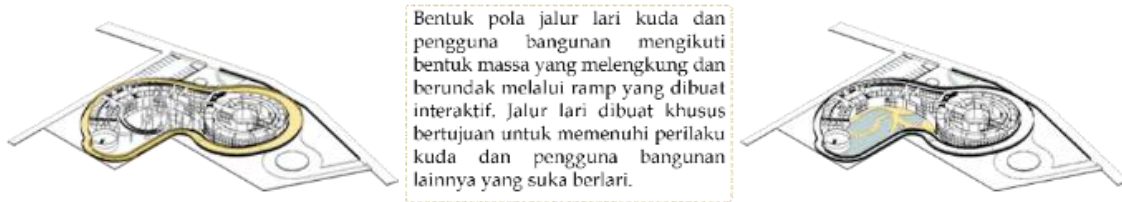

Bentuk pola ruang terbuka didalam tapak dibuat melengkung-lengkung agar dapat senada dengan pola kesan massa serta menciptakan kesan ruang yang intim karena
letaknya di kelilingi massa bangunan.

Ruang Terbuka

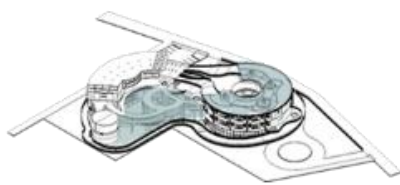

Ruang terbuka hijau tersebar di beberapa titik bangunan, baik di lantai dasar maupun ruang hijau vertikal di setiap lantai dan bagian
lantai atap.

Visual
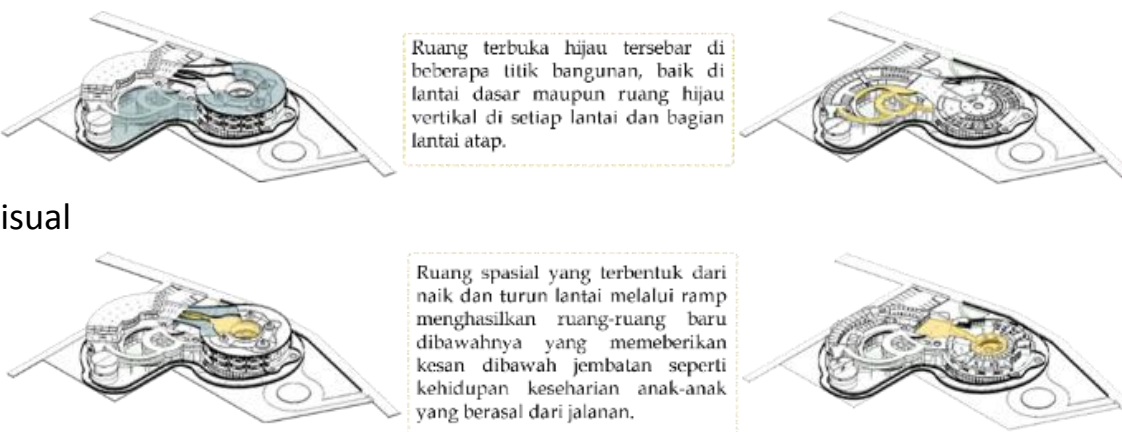

Ruang terbuka hijau juga berada di penghubung yang mengintergerasikan dua zona juga vaitur dapat memiliki juga yaitu area perkebunan permakulturyang dapat dikelola olch berkesplorasi dengan sekitarnya.

Interaksi

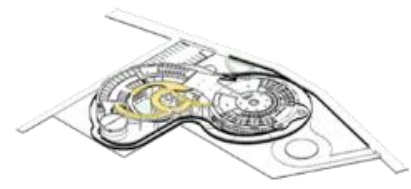
Area perkebunan dengan sistem
permakultur terletak di zona
penghubung karena memiliki posisi
yang strategis untuk dicapai seluruh
pengguna bangunan.

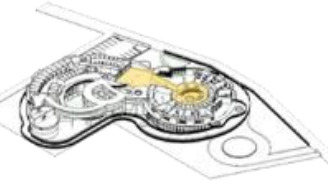

Ruang spasial ditengah bangunan pada zona anak-anak agar tidak interaksi dan kom mench inesar in memiliki privas cukup realisasi dari penerapan panoptic dalam pola bangunan, memudahkan pengawasan terhadap penghuni.

Gambar 5. Strategi Desain Melalui Pendekatan Perilaku dan Panoptik pada Bangunan Sumber: Olahan Pribadi, 2021 


\section{Pengaplikasian}

Aplikasi pendekatan pola Perilaku dan panoptik terhadap ruang-ruang dalam bangunan mencakup beberapa ruang penting, sepeti pada hunian anak, jalur lari, area komunal, ruang terbuka, area kandang, dan ruang lainnya.

1) Hunian Anak

Pada Hunian anak pengaplikasian bentuk pola ruang melalui pendekatan panoptik diterapkan pada letak area komunal atau interaksi terhadap kamar atau ruang istirahat masing-masing anak. Hal ini bertujuan agar para pengawas anak dapat lebih mudah untuk mengkontrol seluruh aktivitas anak secara lebih efisien karena bentuk bangunan yang bulat dan melingkar.

Tabel.1 Pengaplikasian Pendekatan Panoptik

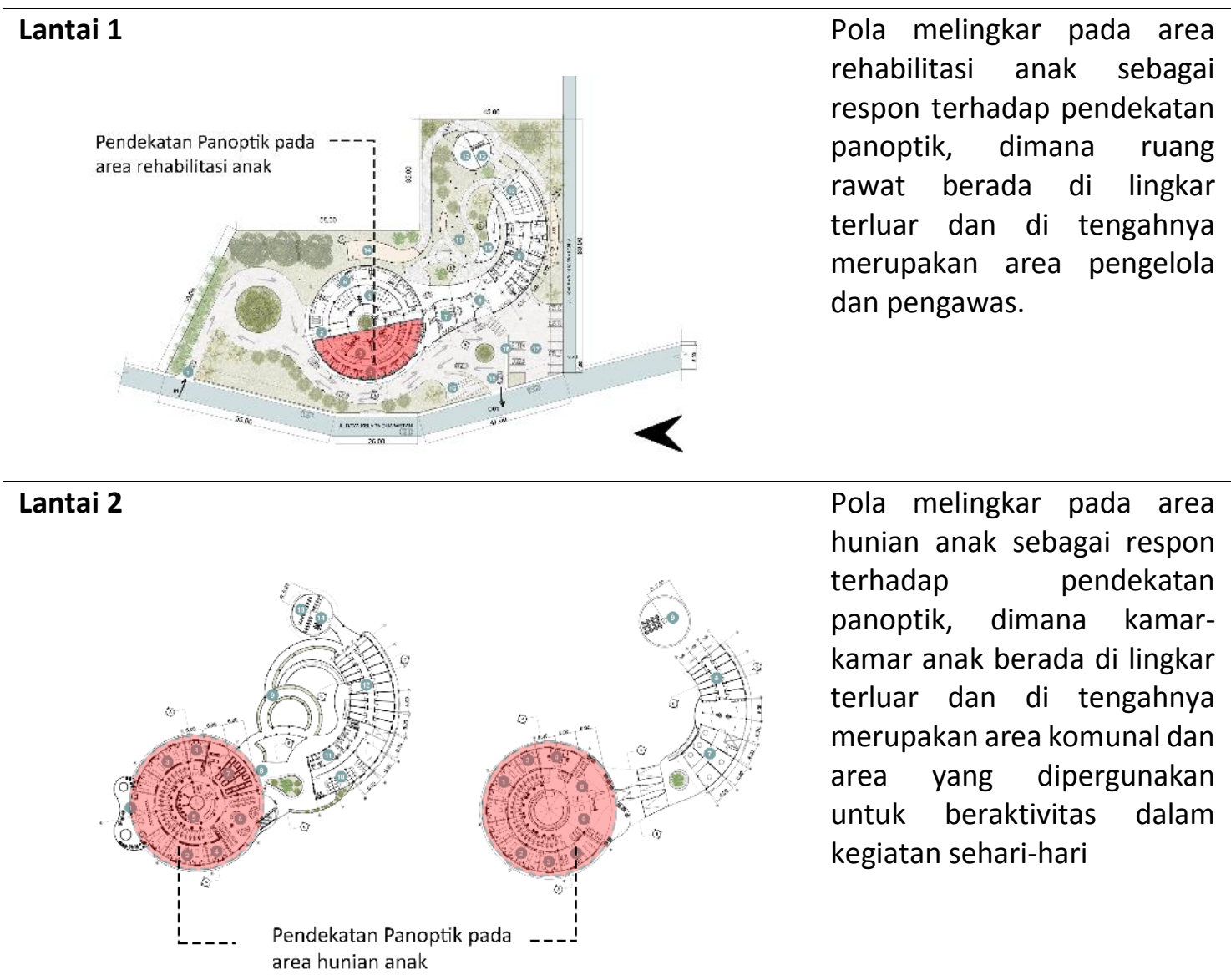

1) Jalur Lari

Jalur lari dibuat melengkung dan naik turun mengelilingi seluruh bangunan mengikuti bentuk dasar massa bangunan. Pengaplikasian turun dan naik serta melengkung bertujuan agar jalur lari tidak serta merta hanya menjadi suatu jalan yang berbeda dan dikhususkan, namun di sisi lain jalur lari menjadi area yang penting dan dapat menjadi wadah untuk berkesplorasi. Jalur lari ini sebenarnya diutamakan untuk kuda, karena kuda mempunya pola tingkah laku dan kebiasaan yaitu berlari, namun dalam konteks bangunan ini yang penghuninya heterogen dan bermacam-macam pola perilakunya, jalur lari ini sebenarnya dapat digunakan oleh seluruh pengguna bangunan dalam waktu-waktu tertentu. 


\section{2) Area Komunal (Roof Garden)}

Seluruh area komunal, baik dalam bangunan maupun berupa ruang terbuka memiliki fungsi lain, bukan hanya sebagai wadah interaksi dan ruang komunal, melainkan terdapat fungsi sebagai area perkebunan, area bermain, area belajar, dan lainnya yang dimana bertujuan untuk membangun interaksi bukan sekedar dari adanya pertemuan antar pengguna bangunan, melainkan terbentuknya suatu interaksi yang berasal dari aktivitas maupun pola tingkah laku pengguna bangunan yang beragam itu sendiri.

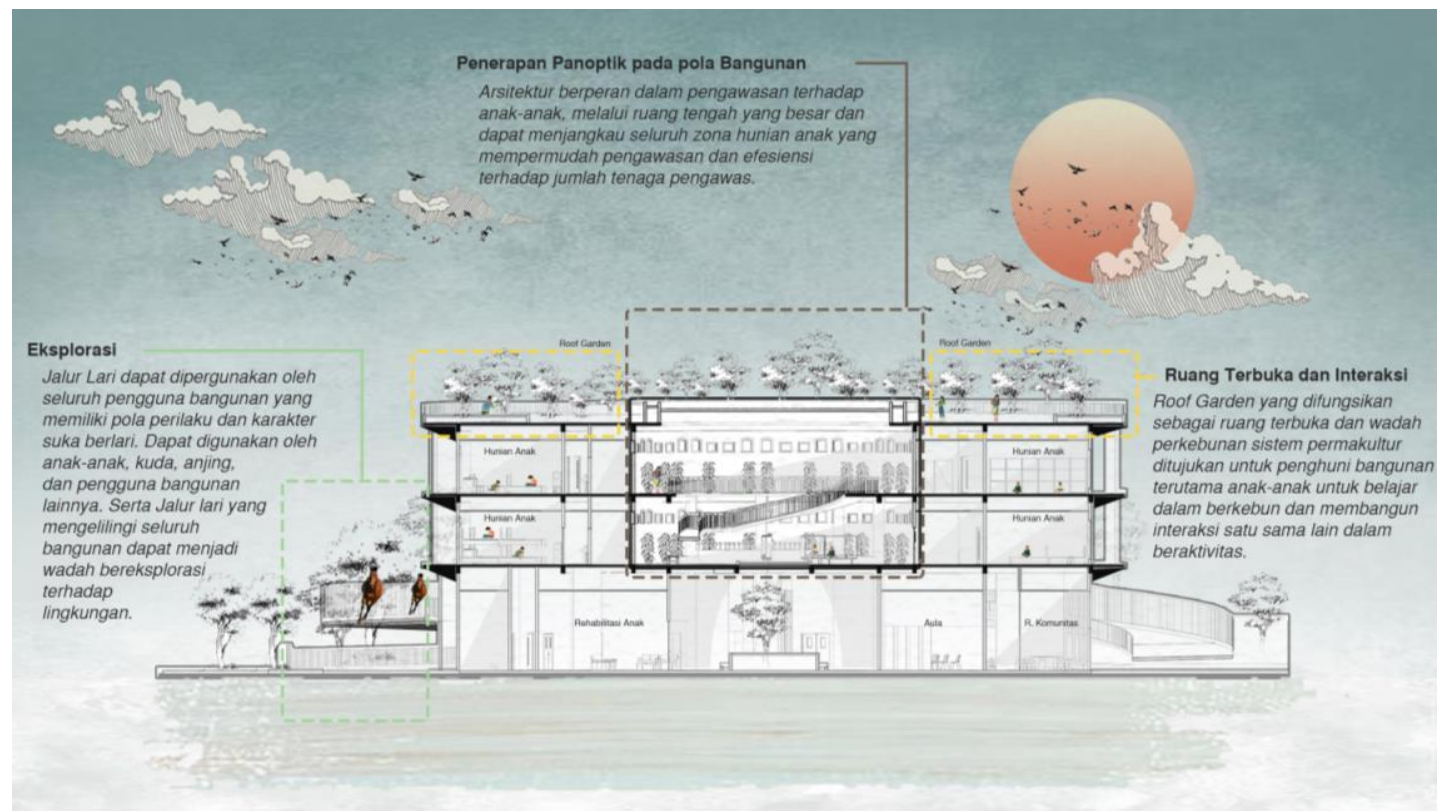

Gambar 6. Potongan Situasi Ruang pada Bangunan Zona Anak Sumber: Olahan Pribadi, 2021

\section{3) Area Kandang Hewan}

Ekosistem yang beragam dan berbeda tentu saja menjadi tantangan tersendiri dalam merancang area kandang yang dibutuhkan, terlebih lahan yang minim di perkotaan membuat area kandang tidak dapat dirancang terlalu luas. Hal ini berkaitan dengan pola tingkah laku masing-masing hewan yang berbeda dan tentu saja setiap jenis hewan harus memiliki areanya tersendiri. Oleh sebab itu, area kandang dirancang vertikal untuk meminimalisir penggunaan lahan yang terbatas, namun perlu adanya proses pengawasan yang efiesien dan setiap area kandang dapat terintegrasi satu sama lain agar mudah dalam segalaproses pengawasan, rehabilitasi, pemberian pakan, dan lainnya. 


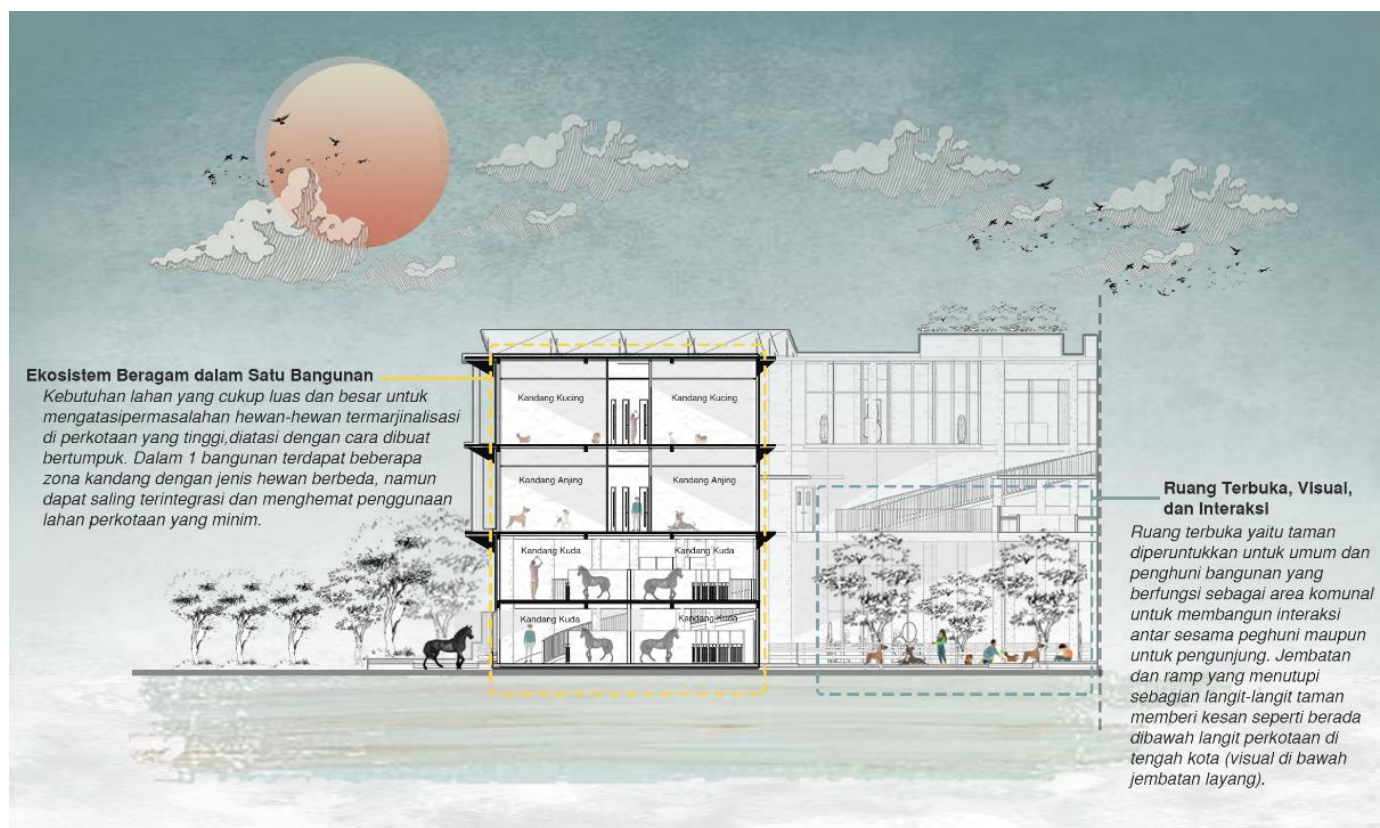

Gambar 7. Potongan Situasi Ruang pada Bangunan Zona Hewan Sumber: Olahan Pribadi, 2021

\section{KESIMPULAN}

Dengan pendekatan pola perilaku sebagai strategi dalam perancangan bangunan dan juga panoptik yang diterapkan dalam pola bentuk massa bangunan juga sebenarnya dapat berperan dalam proses pengawasan terhadap penghuni bangunan, namun tidak bertujuan untuk menakuti bahkan membatasi penghuni, namun membuktikan arsitektur melalui pendekatan panoptik dapat berperan juga dalam proses pengawasan yang baik dan interaktif. Selain itu pendekatan panoptik dapat menjadi suatu strategi desain yang bukan hanya digunakan untuk bangunan yang bertujuan memberikan rasa takut dan diawasi, melainkan dapat diterapkan dalam bangunan dengan fungsi hunian massal dengan lebih interaktif dan tidak menakutkan. Celah Teduh diharapkan dapat menjadi tempat yang layak dan berguna bagi kesejahteraan penghuni kota yang termarjinalisasi khususnya Jakarta, serta menjadi wadah sosial yang dapat melibatkan masyarakat luas agar dapat lebih terbuka dan peduli terhadap persoalan ini.

\section{REFERENSI}

Astriaxanti, D. (2016). Upaya Penanggulangan Masalah Kesejahteraan Anak Jalanan si Yayasan Setara. Semarang: Universitas Negeri Semarang.

Baron, R. (1977). Human Aggression. New York: Plenum Press.

Barton, R. (1966). The patient's personal territory. Psikologi Arsitektur,284.

Bentham, J. (1791). Panopticon Or the Inspection House, Volume 2. London, Inggris.

Bratton, B. (2015). The Stack on Software and Sovereignty. London, Inggris.

Eldija, F. (2016). Panoptic Architecture. Manado: Universitas Sam Ratulangi.

Faucault, M. (1790). Discipline and Punish. New York: Vintage Books, A Division Of Random House.

Fujimori, T. (2010). The Architectures of Atelier Bow-Bow: Behaviorology. New York : Rizzoli.

Indriyati, S.A. (2020). Panduan Perencanaan dan Perancangan Hunian Panti Asuhan Anak. Fakultas Teknik: Universitas Persada Indonesia.

Kementerian Sosial Republik Indonesia. (2011). Standar Nasional Pengasuhan untuk Lembaga Kesejahteraan Sosial Anak. Jakarta.

Lefebvre, H. (1974). The Production of Space. Editions Anthropos. Paris.

Susanto, A. (2020). Peta Metode Desain. Jakarta. 